\title{
Cancer Stem Cell Hypothesis: Implication for Cancer Prevention and Treatment
}

\author{
Anna Meiliana ${ }^{1,2, *}$, Nurrani Mustika Dewi ${ }^{1,2}$, Andi Wijaya ${ }^{1,2,3}$ \\ ${ }^{1}$ Postgraduate Program in Clinical Pharmacy, Faculty of Pharmacy, Padjadjaran University, Jl. Eijkman No.38, Bandung, Indonesia \\ ${ }^{2}$ Prodia Clinical Laboratory, Jl. Cisangkuy No.2, Bandung, Indonesia \\ ${ }^{3}$ Postgraduate Program in Clinical Biochemistry, Faculty of Medicine, Hasanuddin University, Jl. Perintis Kemerdekaan Km.10, Makassar, Indonesia \\ *Corresponding author. E-mail: anna.meiliana@prodia.co.id
}

Received date: Jan13, 2016; Revised date: Feb 16, 2016; Accepted date: Feb 18, 2016

\section{Abstract}

B ACKGROUND: Cancer is a disease of genomic instability, evasion of immune cells, and adaptation of the tumor cells to the changing environment. Genetic heterogeneity caused by tumors and tumor microenvironmental factors forms the basis of aggressive behavior of some cancer cell populations.

CONTENT: Cancers arise in self-renewing cell populations and that the resulting cancers, like their normal organ counterparts, are composed of hierarchically organized cell populations. Self-renewing cancer stem cells (CSC) maintain tumor growth and generate the diverse populations constituting the tumor bulk. CSC in multiple tumor types have been demonstrated to be relatively resistant to radiation and chemotherapy. The clinical relevance of these studies has been supported by neoadjuvant breast cancer trials that demonstrated increases in the proportions of CSC after therapy. The CSC hypothesis has tremendously important clinical implications.

SUMMARY: In summary, a large and accumulating body of evidence supports the CSC hypothesis, which has important implications for cancer prevention and therapy. The ultimate test of this hypothesis will require clinical trials demonstrating that targeting of these pathways reduces cancer incidence and improves outcomes for patients with cancer.

KEYWORDS: somatic mutation, tumor heterogeneity, metastasis, epithelial-mesenchymal transition, CSC niche

Indones Biomed J. 2016; 8(1): 21-36

\section{Introduction}

Cancer is usually viewed as an evolutionary process which results from the accumulation of somatic mutations in the progeny of a normal cell, and leading to a selective growth advantage in the mutated cells and ultimately to uncontrolled proliferation. $(1,2)$ In recent decades, cancer research has characterized the cellular and molecular events which enable the malignant transformation of cells harbouring oncogenic alterations. These events include uncontrolled proliferation; evasion of tumor suppression; inhibition of cell death; creation of a particular microenvironment containing blood vessels, stromal and immune cells; and the acquisition of invasive and metastatic potential.(3) Although many genes leading to different types of cancer when mutated have been identified, the cells that initiate tumor formation following accumulation of these mutations have, until recently, remained elusive.(4)

Several studies have identified a subset of cancer cells, designated as tumor-initiating cell or cancer stem cell (CSC), with the ability for self-renewal and differentiation into distinct cell lineages. Recently, the hypothesis has emerged, and earned great momentum, that tumors are hierarchically arranged, with CSC being the principal drivers of tumor growth for proliferation, resistance to chemotherapy, and metastasis.(5-7) A combination of flowcytometry and xenotransplantation techniques led to the identification of 
leukemia-initiating cells (cluster of differentiation (CD)34 CD38) and breast cancer-initiating cells $\left(\mathrm{CD} 44^{+} \mathrm{CD} 24^{-1 / 0}\right)$ and provided scientific basis for the CSC hypothesis.(7-9)

Development of drug resistance and disease recurrence and metastasis could naturally be the consequences of tumor heterogeneity and plasticity. The latter characteristics also could result in cells having distinct characteristics, including sensitivity to therapy.(10) The hypothesis that tumors arise via sequential mutation and clonal selection has been proposed to be incompatible with a CSC model. In fact, studies such as that of Jan, et al., have provided compelling evidence that both models are correct.(11) Although mutations may occur in any cell, those that occur in non-self-renewing cell populations are extinguished through cellular senescence. CSC mutation may lead to these selective population clonal growth, causing further mutation, and keep continue to mutate and evolve even after full transformation. Thus, cancers may contain multiple CSC clones.(12)

Until now, evidence for the existence of CSC has been controversial, but the hypothesis is extremely attractive because it provides a conceptual framework on which new therapeutic approaches could be built, and is any drug capable of killing CSCs would, in theory, be curative. Now, three independent studies of mouse models of brain (13), skin (14) and intestinal (15) tumors provide the first evidence that CSC do exist and arise de novo during tumor formation in intact organs.(16) Over the last ten years, the notion that tumors are maintained by their own stem cells, has created great excitement in the research community.(17)

\section{CSC Concept}

Despite the advances in cancer treatment, many patients still fail therapy, resulting in disease progression, recurrence and reduced overall survival. Historically, much focus has been on the genetic and biochemical mechanisms which cause drug resistance. Nonetheless, cancer is widely understood as a heterogeneous disease and there is increasing awareness that intratumoral heterogeneity contributes to therapy failure and disease progression.(3) A tumor is not simply a bag of homogeneous malignant cells. Instead, a tumor is a complex ecosystem containing tumor cells, as well as various infiltrating endothelial, hematopoietic, stromal and other cell types which can influence the function of tumor as a whole.(18)

Many leukimias and solid tumors were defined by their pehotypic and functional heterogeneity features, including genetic mutations, epigenetic changes, microenvironment interactions, and if a cellular hierarchy was present or absent. Different cellular mechanisms have been postulated to account for intratumoral heterogeneity.(19) It is now commonly accepted that inherited mutations and environmental carcinogens can lead to the development of premalignant clones (Figure 1).(12) After further mutations, one cell reaches a critical state which confers a survival or growth advantage over the normal cells. Such cells have the ability to initiate a malignant tumor. They share plenty features of normal stem cells, including the capacity for self-renewal and differentiation, and are widely termed CSC.(20) Central to CSC concept is the observation that not all cells in tumors are equal. The CSC concept presupposes that, similar to the growth of normal proliferative tissues such as bone marrow, skin or intestinal epithelium, the growth of tumors is fueled by limited numbers of dedicated stem cells which are capable of self- renewal.(17)

Both CSCs and normal tissue stem cells possess self-renewal capability, however, self-renewal is typically deregulated in CSC. For many cancers, CSC represent a distinct population that can be prospectively isolated from the remainder of the tumor cells and can be shown to have clonal long-term repopulation and self-renewal capacity, the defining features of a CSC. $(21,22)$

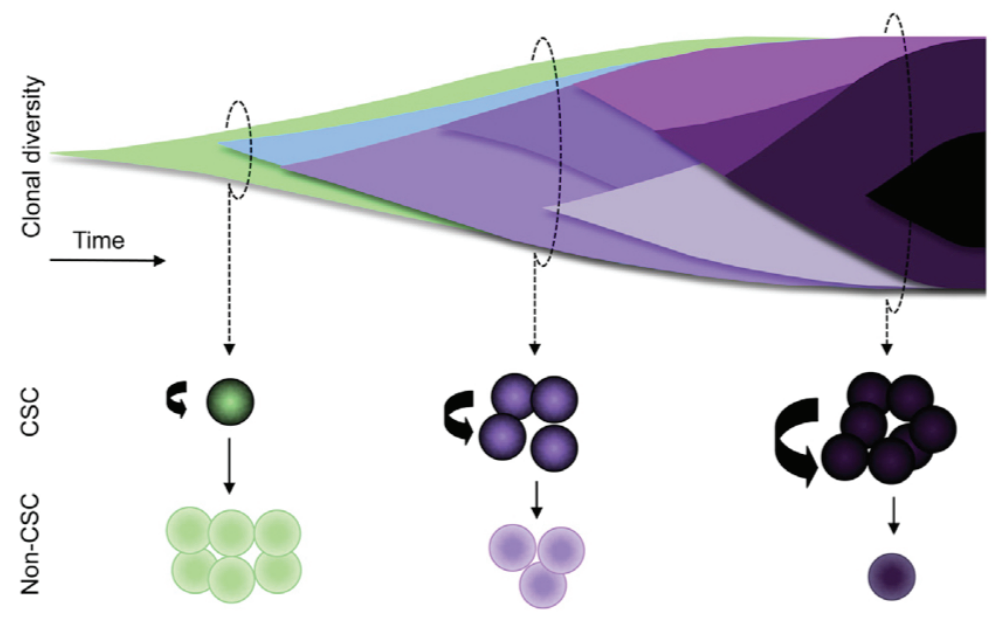

Figure 1. Unified model of clonal evolution and CSC. Top panel shows that acquisition of favorable mutations can result in clonal expansion of the founder cell.(12) (Adapted with permission from Elsevier). 
The CSC hypothesis explains that there exists, within a tumor, a minority cell type which has the characteristics of stem cells, these cells can self-renew and can differentiate to form all of the cell types that constitute the original tumor from a small number of cells.(21) It seems clear that, at least in hematopoetic (23) and some solid tumors including pancreatic (24), prostate $(25)$, colon $(17,26,27)$, breast $(28,29)$, lung $(30)$, and brain $(31,32)$, a small subset of cells can be isolated which can self-renew and form welldifferentiated tumors similar to that of the patient's tumor from which they arise. However, the CSC hypothesis may not be true for all tumor types or for all of these cells all of the time.(33-36) In reality, it has been suggested that stemness may be a dynamic state, which is a function of the cell's interaction with the environment.(37)

The CSC model states that tumors are organized hierarchically with a subset of tumor cells at their apex, which possess self-renewal and multilineage differentiation potential. $(21,38)$ This model therefore suggests that tumors are organized in a similar, albeit distorted, mannered as are their tissues of origin, and could potentially explain several phenomena that are currently incompletely understood. (39) According to the CSC model, minimal residual disease and tumor recurrence after treatment would be a result from remaining therapy-resistant CSC fraction, whereas metastatic potential would be a CSC-specific property. Although these hypotheses are appealing, they lack conclusive experimental evidence.(40)

The definition of CSCs as the only self-renewing tumor cells that capable of seeding a new tumor implies that CSCs are also responsible for initiation of metastases, a notion strengthened by the connection between CSCs and epithelial-mesenchymal transition (EMT) (41-44) which is associated with metastatic behavior and poor prognosis (45). Transient and long-term quiescence, the latter also termed dormancy, are generally believed to be fundamental attributes of adult stem cells. $(46,47)$ On the basis of this premise, stem cells are often identified by their propensity to retain DNA labels much longer than their rapidly proliferating offspring. Dormancy may be a crucial mechanism for the resistance of CSCs to anti-proliferative chemotherapy. Besides, if indeed CSC occur in a dormant state, this would explain the appearance of local recurrence or distant metastasis after long lag periods.(17)

It is often proposed that CSCs are resistant to therapy in the similar way that normal stem cells are protected against insult. These protections include, for example, mechanisms such as quiescence, expression of ATPbinding cassette $(\mathrm{ABC})$ drug pumps, high expression of antiapoptotic proteins and resistance to DNA damage.
(48) Some groups have started to explore if CSCs are indeed more resistant to therapy than their progeny. For instance, CD133-expressing glioma cells survive ionizing radiation better relative to CD133-tumor cells.(49) CD44 hi CD24lo breast cancer CSCs appear intrinsically resistant to conventional chemotherapy (50) and ionizing radiation (51). Meanwhile chronic myeloid leukemia (CML) is sustained by leukemic stem cells that are relatively resistant to the drug Imatinib.(52,53) Nevertheless, the phenomenon of intrinsically therapy-resistant CSCs cannot be generalized, as for instance, the undifferentiated cells which drive testicular germ cell tumors are more sensitive to radiation or cisplatin therapy than their differentiated cellular progeny. (54) Tumor cells that escape therapy, however, may not be endowed with intrinsic therapy resistance. Rather, they may simply be the stochastic winners of the tumor cell-killing process. On the opposite, when intrinsic differences in the sensitivity of cancer cells to therapy do exist, these may also be determined genetically rather than by epigenetic differences.(55)

CSCs must be defined functionally by well-validated assays such as in vivo transplantation instead on the basis of immunophenotype alone. Nevertheless, a number of markers have proven useful for the isolation of subsets enriched for CSCs in multiple types of solid tumors, including CD133, CD44, epithelial cell adhesion molecule (EpCAM), and aldehyde dehydrogenase (ALDH) activity. In the case of human leukemia, a combination of CD34, CD38, and interleukin (IL)-3 receptor subunit alpha (IL3Ra) has enabled the prospective isolation of leukemia stem cells. It should be noted that none of these markers are exclusively expressed by CSCs.(19)

The search for more robust markers of CSCs in glioblastoma and other brain tumors has revealed stagespecific embryonic antigen 1 (SSEA-1)/CD15/Lewis X and a6-integrin. SSEA-1 was identified as a CSC marker in both human glioblastoma and syngeneic mouse models of medulloblastoma.(56-58) Despite a high proportion of specimens lacking $\mathrm{CD} 133^{+}$cells, SSEA-1 enriched for CSCs by 100 -fold in almost every human glioblastoma tumor evaluated.(57) In another approach, the perivascular microenvironment in which brain CSCs reside and identified a6-integrin as a CSC marker that was required for maintenance of CSCs in vivo has been examined.(59) Co-expression of CD133 and a6-integrin was observed in some but not all tumors. The genetic mutation profile may also influence the nature and phenotype of CSCs, as suggested by studies on different genetic mouse models of lung adenocarcinoma (60), whereas epigenetic changes in regulatory genes could impact marker expression itself. 
In breast cancer, even though CD44 and CD24 have been extensively used to isolate CSC, they should not be viewed as universal markers. CD44 and CD24 did not selectively enrich for CSC in estrogen-receptor-negative and triplenegative breast tumors as shown by the fact that CSCs were found in both the CD $44^{+} \mathrm{CD} 24$ and $\mathrm{CD} 44^{+} \mathrm{CD} 24^{+}$fractions. (61) Furthermore, the $\mathrm{ALDH}^{\text {hi }}$ and $\mathrm{CD} 44^{\text {hi }} \mathrm{CD} 24^{\text {lo }} \mathrm{CSC}$ enriched subsets in breast cancer bear little overlap within the same tumor.(62) The same story holds true for colorectal cancer in which the EpCAM ${ }^{\text {hi }} \mathrm{CD}_{4} 4^{+} \mathrm{CSC}$ subpopulation shared minor overlap with CD133 (63), and for pancreatic cancer, where overlap between the $\mathrm{CD} 133^{+}$and $\mathrm{CD} 44^{+}$ CD24 $4^{+}$populations varied considerably between specimens (64). In ovarian cancers, strikingly little concordance was found between CD133 and reported ovarian CSC markers including CD117, CD44, and ALDH1 activity $(65,66)$, most probably explained by many groups relying on cultured cells as opposed to freshly sorted tumors. Finally, in patients with non-small cell lung cancer, even though CD133, CD44, and EpCAM proved ineffective for the isolation of CSC, CD166 showed as a robust marker in more than $50 \%$ of cases.(67) Nevertheless, a combination of markers can refine the CSC phenotype.(19)

Mutations directly influence the stemness and EMT qualities, whereas differentiation and reversion to the CSC state affect the potential of these mutations to be passed on to progeny. The addition of microenvironmental cues to this model discloses a system that is constantly being fine-tuned to provide an optimal tumor-supporting setting.(40) From a cell biological perspective, the link between EMT, migratory $\mathrm{CSCs}$ and metastatic potential is intriguing, but further molecular insight is needed to fully understand and prove these connections. The observation that EMT regulators, such as Snail and zinc-finger-E-box-binding (Zeb)1, can be switched on and off in tumors as a result of a molecular circuitry that involves micro-RNA-dependent regulation provides a starting point.(68-70) Identifying the cues that control the activity of this network will further elucidate the process and will likely also provide targets which can modulate metastasis and interfere with CSC qualities.

From a clinical perspective, our understanding of the interactions between CSCs, differentiated tumor cells and the microenvironment is of utmost importance. As CSCs have been suggested to selectively resist therapy, these interactions are not only important to understand treatment outcome, but could also provide useful targets for therapy. $(39,71)$ Based on this, the next ten years will transform CSCs from an intensely debated concept to a better understood and actively targeted tumor property.

\section{Origin of CSC}

The cell of origin for CSC is a fundamental question in the field that remains unanswered at this time. A common notion is that normal pluripotent stem and/or progenitor cells may be the cell of origin for CSC because these two cell types possess similar hallmark functional characteristics, namely, self-renewal and differentiation. However, there is a lack of experimental evidence to provide insight into the molecular mechanisms required to reprogram normal pluripotent cells into CSC. The most logical and straightforward hypothesis is that accumulation of genetic alterations may trigger the transformation of normal pluripotent cells into CSC. It is unclear whether a distinct set and/or a threshold number of genetic alterations are needed to drive the transition of normal pluripotent cells into CSC.(72) Emerging literature is revealing bidirectional plasticity between the non-CSC and CSC populations to support non-CSCs as the cell of origin for CSCs. Several groups reported that non-CSCs can be induced to dedifferentiate into CSCs by co-opting oncogenic pathways and/or through interaction with the microenvironment. A recent study showed that hyperactive kirsten rat sarcoma viral oncogene (KRAS) and Wnt signaling cooperate to dedifferentiate villus cells into intestinal CSC in a nuclear factor-kappaB (NF-kB) dependent fashion. (73) Similarly, KRAS functioned in concert with another oncogene, cellular myelocytomatosis oncogene (Myc), to promote the conversion of differentiated mouse fibroblasts into CSC.(74) Mammary non-CSC epithelial cells were shown to spontaneously dedifferentiate to CSC in vitro and in vivo.(35). In addition, the conversion rate of non-CSC to CSC was more pronounced in vivo, suggesting that the tumor microenvironment may play a critical role in CSC expansion.(35).

The available data suggest that cancer progresses through multistep processes involving both genetic mutations and epigenetic abnormalities. However, it still remains unclear how epigenetic abnormality occurs during cancer development. Previous studies have demonstrated that cancer-promoting inflammatory stimuli induce drastic changes in DNA methylation patterns.(75) These results suggest that external signals could be a cause of epigenetic abnormalities in cancer cells. In contrast, large-scale sequencing projects have identified a number of mutations of epigenetic regulator genes across a wide variety of cancer types.(76) These results clearly demonstrate that some of the epigenetic abnormalities observed in cancers are attributable to genetic mutations and highlight the primary 
role of genetic mutations, even against a background of epigenetic alterations (Figure 2).(77)

Induced pluripotent stem cell (iPSC) derivation processes share many characteristics with cancer development where during reprogramming, somatic differentiated cells will show unlimited proliferation for self-renewal and global alterations for transcriptional program, similar to carcinogenesis critical events.(78) The metabolic switch to glycolysis that occurs during somatic cell reprogramming is similarly observed in cancer development.

(79) Such similarities suggest that reprogramming processes and cancer development may be partly promoted by overlapping mechanisms.(80) Practically, the forced induction of the critical reprogramming factor organic cation transporter (Oct)-3/4 in adult somatic cells results in dysplastic growth in epithelial tissues through the inhibition of cellular differentiation in a manner which is similar to that in embryonic cells.(81) These studies provided a possible link between transcription-factor-mediated reprogramming and cancer development.(82)

Remarkably, the process of dedifferentiation or reprogramming of the somatic cells by Yamanaka factors, many of which are oncogenes, offers a new insight into CSC. These may be the somatic cells dedifferentiation product after oncogenic insult. Cancer cells have an amazing rate of survival. They can even exploit and subvert the cellular machinery by proliferation, dedifferentiation, and even transdifferentiation, to achieve that goal.(83)
There are many parallels between reprogramming and cancer. The similarities between the process of reprogramming cells to iPCS and differentiated tumor cells to CSC propose that some of these mechanisms, like epigenetic resetting, can render cells in a susceptible condition where genetic alterations are only the next step toward transformation and tumor progression. Knowing the mechanisms governing cellular reprogramming and induced pluripotency may shed light into deciphering the processes involved in tumorigenesis.(83) The notion that Oct-4 induction influences the epigenetic regulations and contributes to the maintenance of undifferentiated proliferating cells may provide a possible link between transcription factor-mediated reprogramming and oncogenesis.(81) SRY (sex determining region Y)-box 2 (Sox2) is amplified in lung and esophagus cancer and is an essential driver of CSCs subpopulations in glioblastoma, breast cancer, and Ewing sarcoma.(84,85) A large variety of human malignancies express high levels of Myc. Its expression may explain the observation that most of the mice generated with iPSC clones spontaneously developed tumors.(86) Myc is an important transcriptional regulator in embryonic stem cell, and it significantly promotes the process of iPSC derivation. Its role as a global amplifier of gene expression not surprisingly also drives a wide range of malignant programs.(87) The list can go on including Kruppel-like factor 4 (KLF4), Nanog, Lin28, and other pluripotency factors and transcription factors which mediate

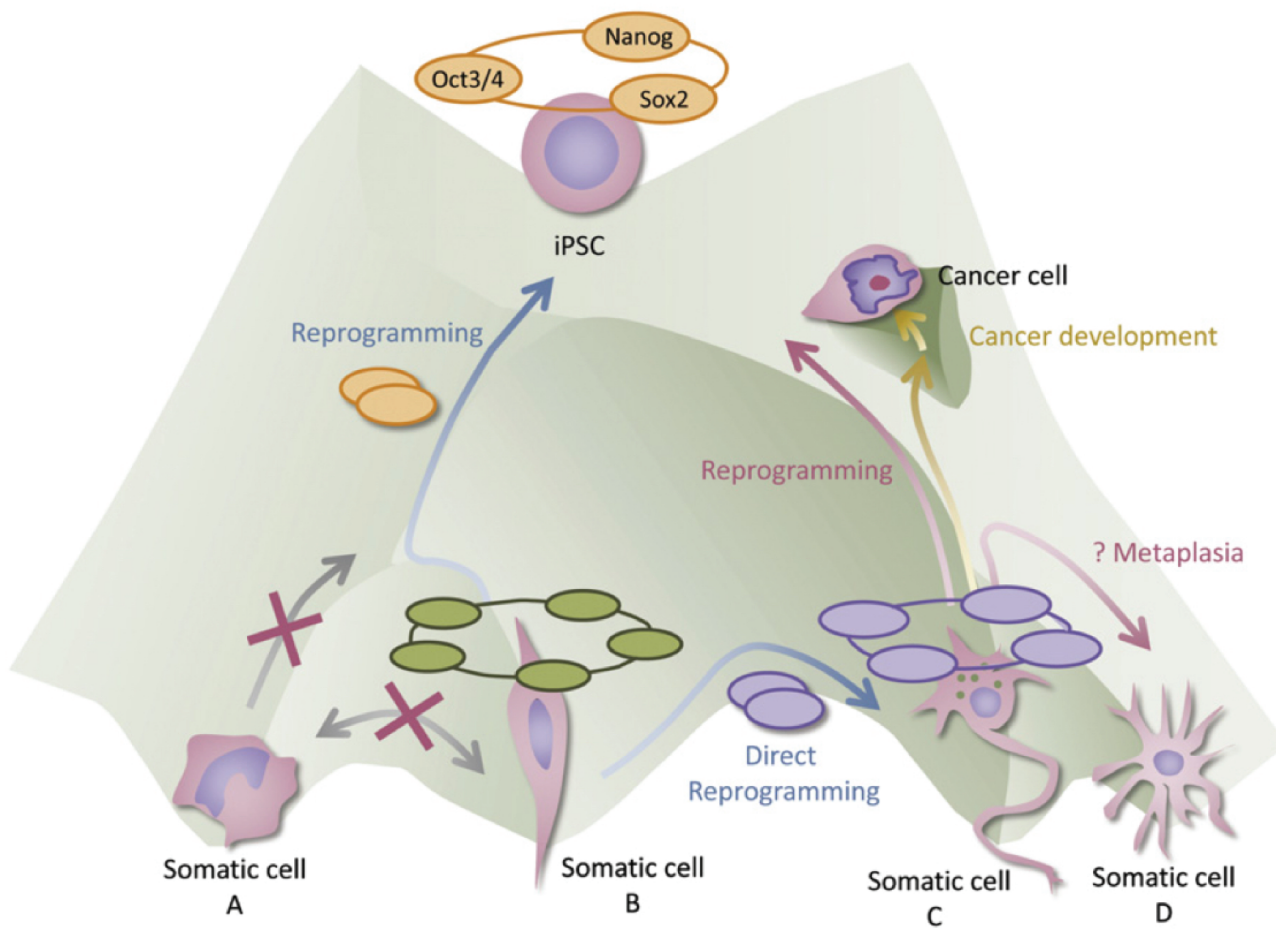

Figure 2. Dedifferentiationdriven cancer development in an epigenetic landscape. (77) (Adapted with permission from AlphaMed Press). 
direct lineage conversion, emphasizing the link between reprogramming and oncogenesis. $(88,89)$ The convergence and commonality of CSC and iPSC opens a new avenue to develop therapeutic approaches to fight recurring cancers.

\section{EMT}

Initially described as epithelial to mesenchymal transformation, this differentiation process is now generally known as EMT to emphasize its transient nature. Meanwhile mesenchymal-epithelial transition (MET) describes the reverse process. The ability of epithelial cells to do a transition into mesenchymal cells and back, either partially or fully, illustrates an inherent plasticity of the epithelial phenotype. During EMT, epithelial cells lose their junctions and apical-basal polarity, reorganize their cytoskeleton, undergo a change in the signaling programmed that define cell shape and reprogrammed gene expression; this increases the motility of individual cells and enables the development of an invasive phenotype. $(90,91)$ EMT is integral to development, and the processes underlying it are reactivated in wound healing, fibrosis and cancer progression.(91-93)

The changes in gene expression that contribute to the repression of the epithelial phenotype and activation of the mesenchymal phenotype involve master regulators, including Snail, Twist and Zeb transcription factors. Their expression is activated early in EMT, and in this way, they have central roles in development, fibrosis and cancer. (94) Vascular endothelial growth factor (VEGF) signaling promotes EMT in pancreatic and breast tumor cells by inducing Snail and Twist expression. $(95,96)$ Interestingly, Snaill can induce VEGF expression in epithelial cells (97), and they are coexpressed during peritoneal fibrosis (98). Thus, a regulatory loop between angiogenesis and EMT may contribute to tumor progression.

Tumors can escape immune surveillance by inducing tolerance or by modifying their phenotype through immunoediting. Indeed, Neu-driven tumors escape immune surveillance upon undergoing EMT.(99) Tumor relapse is found in a $\mathrm{Neu} / \mathrm{ErBb} 2$-inducible transgenic tumor model after removal of the inducer, indicating that tumors rely on continuous oncogenic signaling. However, all animals had residual foci that finally developed more aggressive new tumors of the EMT type.(100) These two studies suggest that EMT may be involved in the acquisition of resistance to targeted therapies and that cells belonging to the foci of minimal residual disease acquired a mesenchymal phenotype. (94) Tumors undergoing EMT may resist conventional chemotherapy, and subsequently, colon carcinoma epithelial cell lines made resistant to oxaliplatin exhibit a mesenchymal morphology and express several markers of EMT.(101) The resistance of ovarian carcinoma epithelial cell lines to Paclitaxel is also correlated to the acquisition of EMT markers and loss of the epithelial phenotype.(102) Twist and one of its target genes are elevated in a subset of Michigan Cancer Foundation-7 (MCF7) or human metastatic MDA-MB-434 cells selected for their invasive properties, and having undergone EMT, they were also resistant to Paclitaxel.(103) Moreover, the depletion of Twist can partially reverse multidrug resistance (MDR) in breast cancer cells.(104) EMT is required for primary carcinoma to invade and disseminate, because these pioneer invasive cells have important features (mesenchymal and a stem celllike phenotype) which can initiate a differentiated epitheliallike structure. A reversion process of this differentiated phenotype through a process of MET is important for macrometastasis formation and next forming a bulk of the secondary tumor mass. This hypothesis was formulated earlier from an analysis of the progression of colon primary tumors and liver metastases, where it was proposed that CSC could acquire a mesenchymal phenotype, and thereby become migratory CSC that will form metastasis.(44)

Consistent with the reversible nature of EMT, differentiated cancer cells can do a transition into CSC, and vice versa, enabling oncogenic mutations which arose in differentiated cancer cells to integrate through EMT into CSC as EMT promotes cell invasion that leads to tumor cell dissemination, this procedure enables CSC with new oncogenic mutations to clonally expand, following invasion, dissemination and MET in secondary tumors. $(44,105)$ In cancer, both EMT and CSC generation have been associated with transforming growth factor (TGF) $-\beta$ signaling. For example, breast cancer CSCs show higher levels of TGF- $\beta 1$ and type II TGF- $\beta 1$ receptor expression than the more differentiated cells, and inhibition of TGF- $\beta$ signaling in CSCs re-establishes an epithelial phenotype. (106) Also, Wnt and Notch signaling are associated with CSCs. Colon CSCs show a high level of Wnt signaling, with nuclear $\beta$-catenin at the invasive cancer front and in scattered tumor cells. $(107,108)$ Notch signaling contributes to the generation of CSCs in other cancers (109), including pancreatic adenocarcinomas (110), and the inhibition of Notch signaling suppresses EMT and CSCs in a xenograft model (111).

Regulating the activity of E-cadherin repressors may seem an obvious strategy to combat cancer progression. However, these inducers of the full EMT program are 
transcription factors, and are very difficult to target. RNA interference provides some hope in terms of specificity, but further development is indeed needed to increase the stability of these reagents and the efficiency in cell targeting and intracellular delivery.(91) Small-molecule inhibitors or antibodies directed against the epidermal growth factor receptor (EGFR), insulin-like growth factor receptor (IGFR), platelet-derived growth factor receptor (PDGFR), hepatocyte growth factor receptor (HGFR), TGF- $\beta$ receptor (TGF $\beta R$ ), and endothelin type A receptor (ETAR) have been effective in preclinical and clinical trials. Although initially developed as inhibitors of cell proliferation or angiogenesis, it is likely that these molecules interfere with EMT.(112) For instance, Cetuximab or Panitumumab, two antibodies against EGFR, or Erlotinib and Gefitinib, two small molecules that act as competitive inhibitors of the EGFR kinase, are currently used clinically to treat advanced carcinoma. Nevertheles, studies in cell lines show that not all cells expressing high levels of EGFR respond to Erlotinib or Gefitinib. Interestingly, there is an obvious correlation between the EMT status of each cell line and the degree of response.(113-115) Another approach to overcome refractoriness is to target directly the CSC. Lately, salinomycin was identified from a library consisting of 16,000 small molecules for its selective cytotoxity toward enriched breast CSC. This pioneer study provides a proof of principle that CSC exhibiting EMT features can be selectively targeted by drugs.(116)

\section{The CSC Nische}

CSCs are tumor cells which have the principal properties of self-renewal, clonal tumor initiation capacity, and clonal long-term repopulation potential. $(21,22)$ They also display plasticity by reversibly transitioning between stem and non-stem cell states. CSCs have the capability to evade cell death and metastasize, although they may stay dormant for long periods of time.(117) Both experimental models and clinical studies indicate that CSCs survive many commonly employed cancer therapeutics.(18)

As is the case for normal stem cells, CSCs are believed to reside in niches. Niches are specialized microenvironments which regulate adult stem cell fate by providing cues in form of both cell-cell contacts and secreted factors. Niches have been identified for mammalian stem cells in various epithelial tissues, such as the intestine as well as in neural, epidermal, and hematopoietic systems.(118) Normal niches are comprised of fibroblastic cells, immune cells, endothelial and perivascular cells or their progenitors, extracellular matrix (ECM) components, and networks of cytokines and growth factors.(119) The CSC niche itself is a part of the tumor microenvironment, which is a collective term for the adjacent stroma along with the normal counterparts of tumorigenic cells.(120) Non-CSC tumor cells are also part of the CSC niche. During the progression of tumors to a more malignant state, the CSC state in primary tumor depends crucially on the tumor microenvironment and potentially on the CSC niches within it.(121) CSCs are metastatic cancer cells that can self-renew. Their plasticity and dormancy correlates with their therapeutic resistance (Figure 3).(122)

Metastasis happened when disseminated cancer cells, away from the primary site, recreate a full-fledged tumor in another tissues. How the cancer cells can move from a tumor to a distant organ via circulation is still become the interest of cancer biologist and clinical oncologist. The latest findings have started to define the sources, phenotypic properties, hosting niches, and signaling pathways which support the survival, self-renewal, dormancy and reactivation of cancer cells that initiate metastasis, that is metastatic stem cells. (123)

Metastatic growth in distant organs is the major reason of cancer mortality. The development of metastasis is a multistage process with several rate-limiting steps.(124) Even though dissemination of tumor cells seems to be an early and frequent event (125), the successful initiation of metastatic growth, a process termed metastatic colonization, is not efficient for many cancer types and is accomplished only by a minority of cancer cells that reach distant sites $(126,127)$. Prevalent target sites are characteristic of many tumor entities (128), proposing that inadequate support by distant tissues contributes to the inefficiency of metastatic process. Small population of CSC is critical for metastatic colonization, that is, the initial expansion of cancer cells at the secondary site, and that stromal niche signals are vital to this expansion process (Figure 4).(122) A component of the ECM, called Periostin (POSTN), is expressed by fibroblasts in normal tissue and in stroma of the primary tumor. Infiltrating tumor cells have to induce stromal POSTN expression in the secondary target organ (in this case lung) to initiate colonization. POSTN is required to allow CSC maintenance, and blocking its function avoids metastasis. POSTN recruits Wnt ligands and thereby increases Wnt signaling in CSC. The education of stromal cells by infiltrating tumor cells is an crucial step in metastatic colonization and that preventing de novo niche formation may be a novel strategy for the treatment of metastatic disease.(129) 


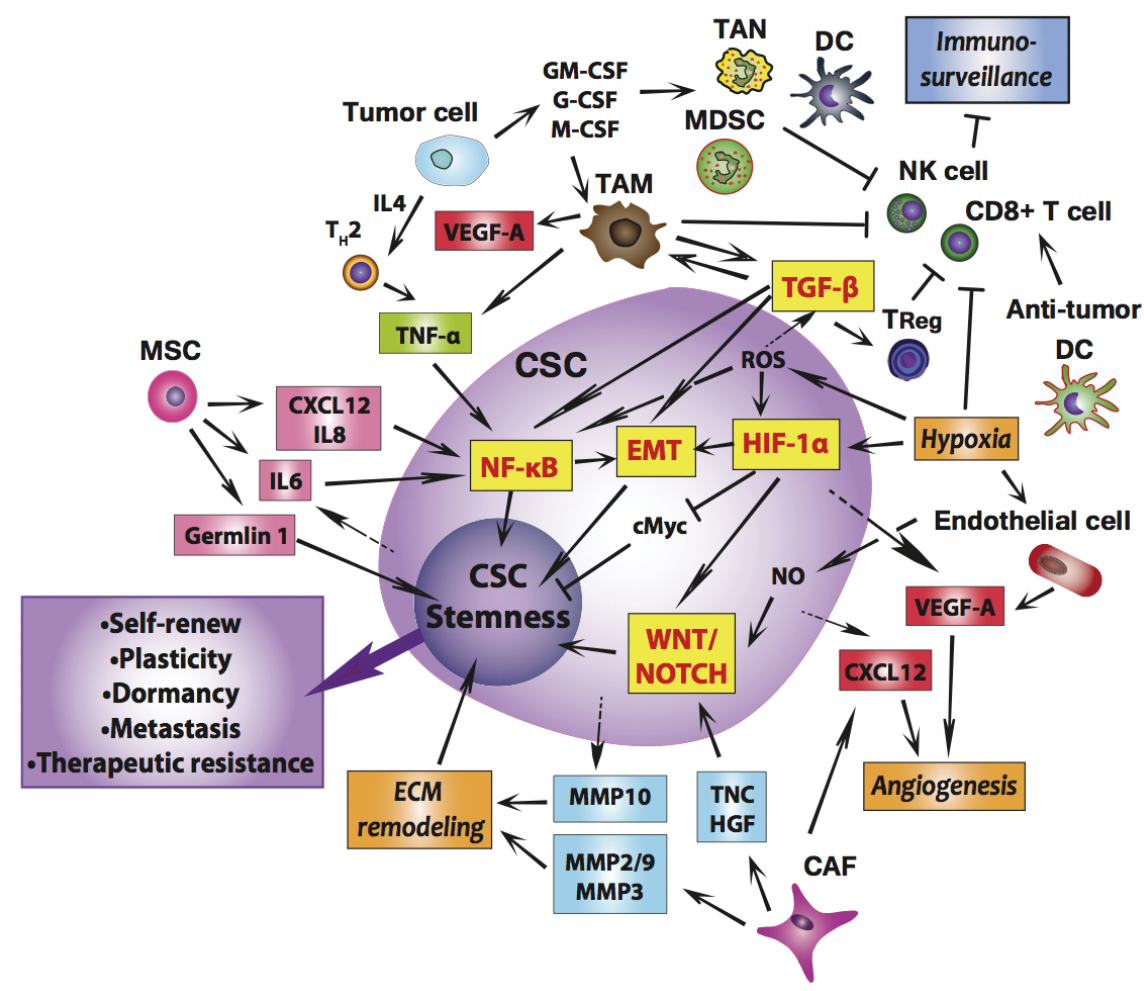

Figure 3. The molecular and cellular basis of the cross talk between CSCs and their niches.(122) DC: dendritic cell, MDSC: myeloid-derived suppressor cell, TAN: tumor-associated neutrophil, TAM: tumorassociated macrophage, NK: natural killer, GM-CSF: granulocyte-macrophage colonystimulating factor, G-CSF: granulocytecolony stimulating factor, M-CSF: macrophage colony-stimulating factor, TNF- $\alpha$ : tumor necrosis factor alpha, MSC: mesenchymal stem cells, CXCL: chemokine $\mathrm{C}-\mathrm{X}-\mathrm{C}$ motif ligand, ROS: reactive oxygen species, HIF-1 $\alpha$ : hypoxia-inducible factor 1-alpha, CAF: cancer-associated fibroblasts, MMP: matrix metalloproteinase, TNC: tenascin $\mathrm{C}$, HGF: hepatocyte growth factor. (Adapted with permission from Elsevier).
Organs are composed of the cells which perform the main organ function (e.g., secrete hormones or enzymes) and the stroma (from Latin or Greek, often translated as mat or bed), the supportive framework of an organ. The stroma can be divided into several classes, there are the ECM, which is composed of proteoglycans, hyaluronic acid and fibrous proteins (e.g., collagen, fibronectin, and laminin), and stromal cells. The stromal cells include mesenchymal supporting cells (e.g., fibroblasts and adipocytes), cells of the vascular system, and cells of the immune system. Various peptide factors (e.g., growth factors, chemokines, cytokines, antibodies) and metabolites are also found in the stroma. The stroma is essential for normal organ development. (130-132) Different components of tumor stroma similarly affect the progression of the tumor. As tumors develop and progress, they undergo dramatic morphological changes $(133,134)$, which also involves the stroma $(133,135-137)$. The importance of stage-specific changes of the stroma is not yet completely comprehensible. However, in most cases the stroma of the later stages is more supportive of tumor progression than the stroma of early stages.(138)

Just as normal developing organs, such as liver and kidneys, have systemic consequences for the organism, so does tumor organ. The dramatic systemic effects of the tumor organ are not limited to metastatic spread, but also include effects on immunity, coagulation and metabolism. Certainly it is these major systemic changes which cause the majority of cancer deaths, rather than effects of the direct overgrowth of the primary tumor or even the metastases. (138) To prevent malignancy and metastasis, CSCs need to be eradicated. Due to their plasticity, this could be tricky to find a specific niche component target that relevant to particular cancer type so a standard promising cancer therapy can tackle the tumor bulk effectively. Thus, we need a better understanding of CSCs biology and niche factors of each cancer subtype, and their modulation to various therapeutic design to develop a fully applicable therapy strategy in the clinic. (122)

\section{Mechanism of Therapy Resistance in CSC}

CSCs have lately been identified and characterized in many types of solid tumors and may have role in treatment failure since they have been shown to be relatively resistant to conventional therapies. Recent data propose that both intrinsic and extrinsic determinants confer radioresistance to CSC through a variety of mechanisms.(139) Traditional cancer therapies typically target the rapidly dividing tumor cells, yet, some cells of the tumor are spared.(140142) These spared tumor cells which are reported to be present within abundant amount of tumor types exhibit the potential to regenerate and are called CSCs.(140-144) This may explain the clinical scenario in which a tumor has an 

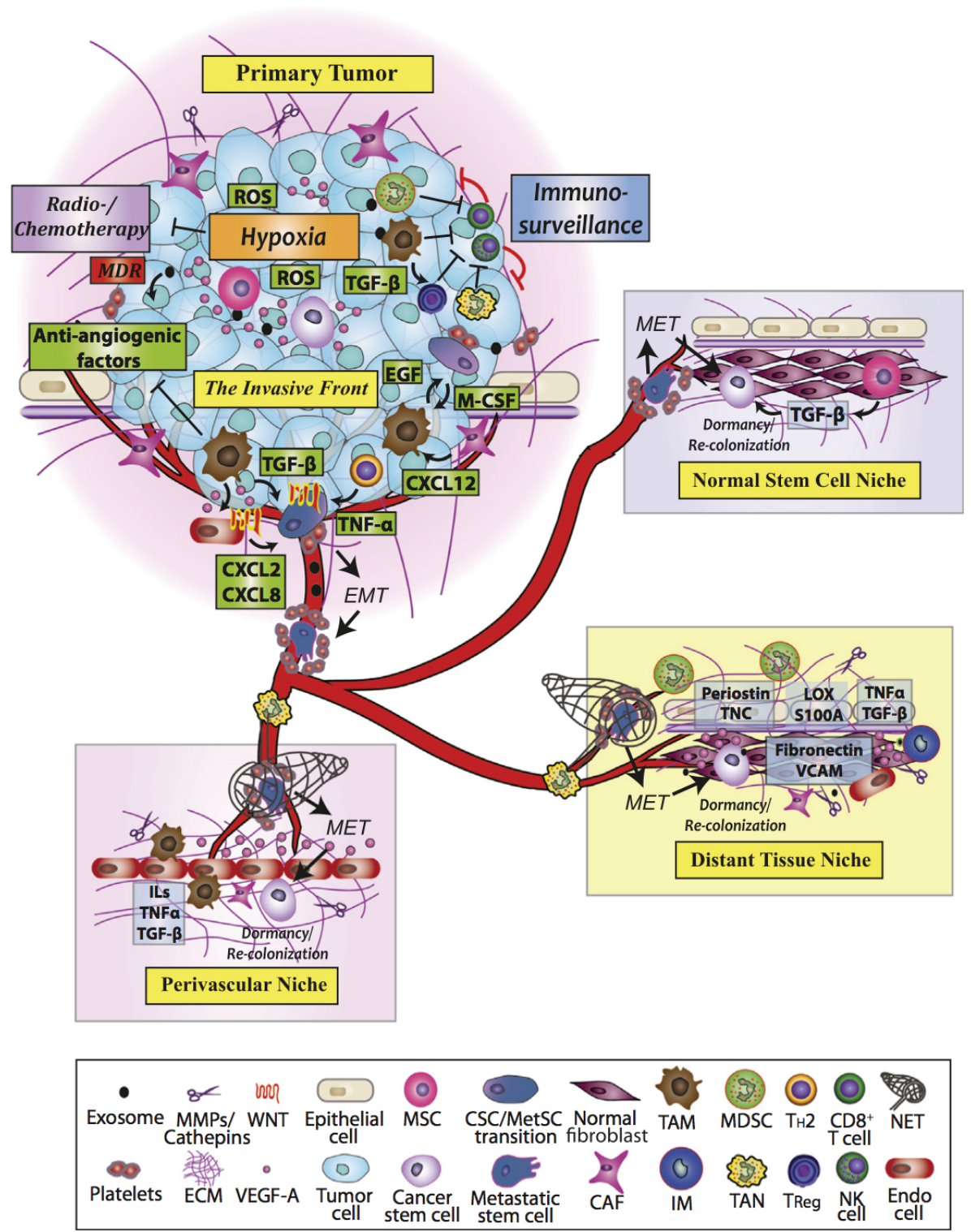

Figure 4. CSC niches in the primary tumor and metastasis.(122) EGF: epidermal growth factor, LOX: enzyme lysyl oxidase, VCAM: vascular cell adhesion molecule, NET: norepinephrine transporter, IM: intramuscular. (Adapted with permission from Elsevier).

apparent volumetric reduction, however, is subsequently followed by local recurrence. While debate continues as to the precise identity and function of CSCs, there is common agreement that CSCs show increased chemoresistance and radioresistance.(140-142,145) Therefore, understanding the biology of chemoresistance potential of CSCs may contribute to our understanding of tumor biology and would have far-reaching clinical implications.

Mechanisms of radioresistance in CSC include: CSCs display enhanced DNA repair activity, at least in part due to enhanced activation of the DNA damage checkpoint. $(1,2)$ CSCs contain lower reactive oxygen species (ROS) levels and overexpress ROS scavengers, resulting in less DNA damage after ionizing radiation.(3) CSCs can induce autophagy to promote survival.(4) The canonical Wnt/ $\beta$ catenin signaling pathway and (5) the Notch signaling pathway are over-activated in CSCs, leading to upregulated transcription of genes responsible for cell proliferation and survival.(6) CSCs may be located in hypoxic niches within tumors which would contribute to resistance to radiation. (139) There is raising evidence that polycomb group (PcG) proteins (discovered in Drosophila as epigenetic gene silencers) play an important role in cancer development and recurrence. PcG of proteins is composed of two multimeric protein complexes, which are the polycomb repressive complex (PRC)1 and PRC2.(146) The PRC1 complex includes B cell-specific Moloney murine leukemia virus integration site 1 (BMI1), Mel-18, Mph1/Rae28, M33, sex comb on midleg homolog 1 (SCMH1) and Ring2, meanwhile the PRC2 complex includes Eed, EzH, Suz12, and YY1.(146) BMI1 is reported to play a crucial role in self-renewal of stem cells and is associated with a number 
of human malignancies.(141,144,147-149) Recent studies suggest that BMI1 is involved in the initiation of cancer, and targeting BMI1 by gene therapy abolishes chemoresistance in tumor cells. $(141,142)$

The inability of tumor cells to go through apoptosis in response to chemotherapy gives a selective advantage for tumor progression, metastasis, and resistance to therapy. BMI1 has been known to be associated with the protection of tumor cells from apoptosis. Cui, et al., showed that the ectopic expression of BMI1 rescues keratinocytes from stress-induced apoptosis.(148) BMI1 knockdown was observed to increase the apoptosis in lymphocytes in spleen and thymus in an animal model.(150) Zhang, et al., observed that ovarian CSCs exhibiting high BMI1 levels have increased resistance to Cisplatin and Paclitaxel.(151) Crea, et al., showed that BMI1 silencing significantly enhanced the antitumor efficiency of Docetaxel against prostate cancer cells. BMI1 (by modulating antioxidant machinery) was observed to allow prostate tumor cells to survive after the chemotherapy.(142) Examination of clinical datasets revealed a positive correlation of BMI1 and antioxidant gene expression in patients exhibiting chemoresistance. (142) Recently, Wang, et al., reported that BMI1 is involved in chemoresistance of ovarian cancer cells, and targeting BMI1 by gene therapy sensitizes tumor cells to Cisplatin chemotherapy.(152) Modulation of reduced glutathione, checkpoint kinase 2 (CHK2) and H2A histone family, member $\mathrm{X}(\mathrm{H} 2 \mathrm{AX})$ molecules by BMI1 was reported as the underlying mechanism for chemoresistant behavior of ovarian tumor cells.(152)

Chemoresistance has been reported to be caused by the aberration of several molecular pathways in tumor cells. CSCs have been shown to display chemoresistance through (a) modulation of DNA repair machinery, (b) ABC MDR, (c) quiescence, and (d) upregulation of antiapoptotic genes. (153) Emerging evidences support the notion that BMI1 is an important molecule in the process of chemoresistance. But the precise mechanism of BMI1 on the regulation of chemoresistance in tumor cells is no fully understood. It is reported that BMI1 modulates several molecular pathways within the cells. BMI1 has been shown to induce its effect at epigenetic as well as genetic level.(146,154,155) It is believed that chromatin modifications induced by $\mathrm{PcG}$ proteins, including BMI1, form an obstacle to transcription factors and RNA polymerase binding.(155,156) BMI1 has been reported to be associated with the progression, recurrence, and chemoresistance to the various types of cancer cells. Hence, it is of great clinical value to further understand the molecular mechanism underlying the regulation of BMI1 in CSCs and chemoresistance. This will not only help in understanding the role of BMI1 in the growth of CSCs and chemoresistance but will also provide insights for the establishment and development of new strategies and effective clinical therapies for the treatment of chemoresistant cancers.(156)

\section{Targeting CSC Therapies}

A growing body of studies indicates that CSCs are intrinsically more resistant to chemotherapeutic agents and radiation than the bulk of tumor cells, and thus play an important role in persistence of cancer residual disease and recurrence. This drug resistance in CSCs has been attributed to highly expressed drug efflux pumps (for example, the MDR proteins), enhanced DNA repair proteins, expression of antiapoptotic proteins, and a slow rate of cell proliferation. (157) Thus, it is important to develop effective therapeutic strategies to eliminate CSCs and overcome cancer resistance to chemotherapy and radiotherapy.(158)

Conventional anticancer approaches are directed predominantly at bulk tumor populations. That kind of strategies often have limited efficacy because of the intrinsic or acquired drug resistance and/or resistance to ionizing radiation.(160) Mechanisms of therapeutic resistance include increased recognition and repair of DNA damaged by the drug or ionizing radiation, altered cell cycle checkpoint control, impaired functioning of apoptotic pathways, and reduced drug accumulation as a result of increased expression of $\mathrm{ABC}$ transporters which efflux drug.(160,161) Evidence has showed that CSCs represent a subpopulation of cells within cancers that is characterized by increased resistance to chemo- and radiotherapy, indicating that conventional anticancer approaches might frequently fail to eradicate the cell subset which initiates and perpetuates tumorigenesis (Figure 5).(159) For example, CSC chemoresistance has been reported in human leukemias (162-169), in malignant melanoma $(169,170)$, and in brain (171), breast $(50,172)$, pancreatic (64), and colorectal (173) cancers. Furthermore, CSC radioresistance has been identified in brain $(48)$ and breast $(51,174)$ cancers. CSCs in human indeed are the major culprits for tumor development, malignant progression, and responsible for therapeutic resistance. CSCs then were a potential target for effectively treatments and reducing the tumor relapse and metastasis.(159)

A number of therapeutic strategies directed at CSC are beginning to be experimentally confirmed. These 


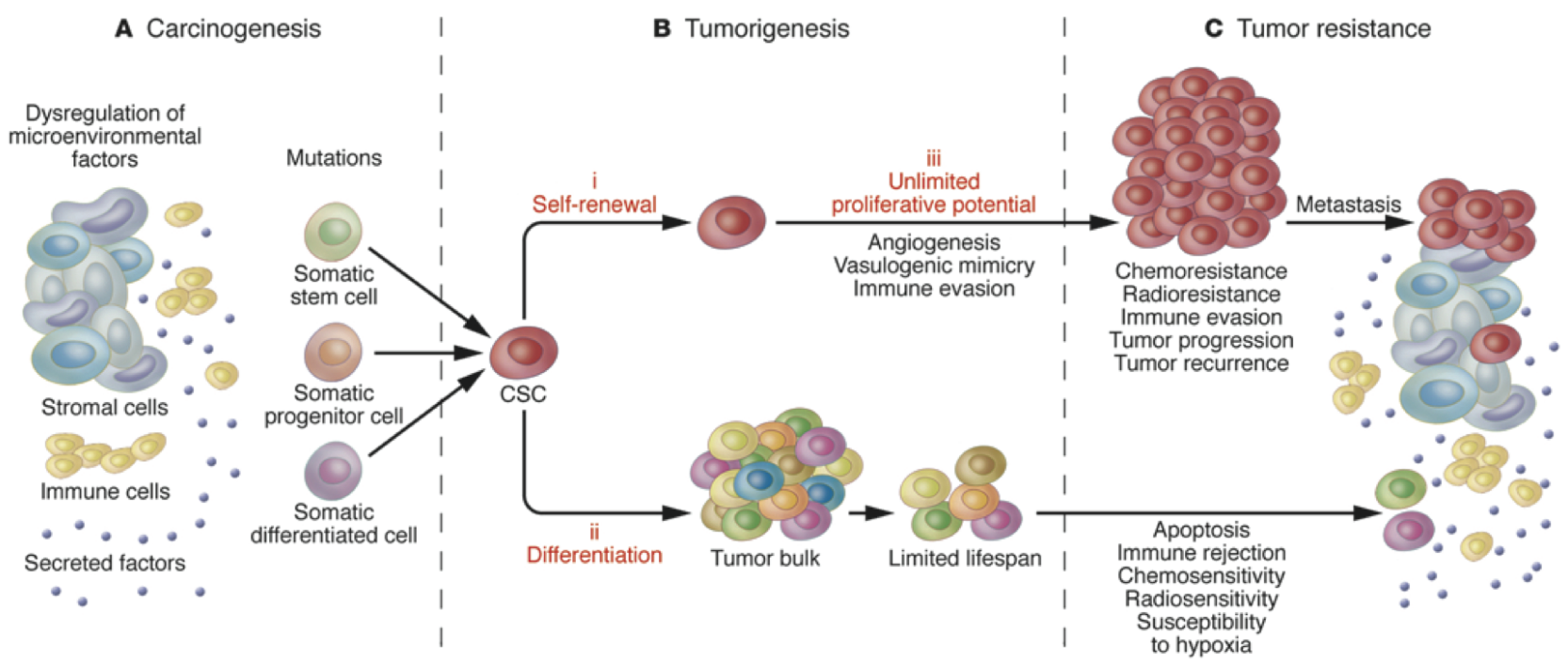

Figure 5. CSCs, carcinogenesis, tumorigenesis, and tumor resistance.(159) (Adapted with permission from American Society for Clinical Investigation).

approaches could potentially intensify responsiveness to current anticancer treatment regimens and might reduce the risk of relapse and dissemination. The approaches include ablation using antitumor agents which target prospective markers of CSCs (e.g., monoclonal antibodies and activated immune cells), reversal of chemo- or radio-resistance mechanisms operative in CSC, CSC pathway interference, differentiation therapy, disruption of protumorigenic CSC-microenvironment interactions, antiangiogenic or antivasculogenic therapy, and disruption of immunoevasion pathways (Figure 6).(159)

Monoclonal antiboy-based strategies that target molecules expressed by CSCs, for example EpCAM on breast and colon CSCs $(9,63)$, are already being translated to the clinic.(48) These developments underline the therapeutic promise of the CSC concept. Ultimately, patient cures will require eradication of all cells within a cancer. So combination therapies which target both CSCs and bulk cancer populations are tend to emerge as particularly effective clinical strategies, especially in those malignancies currently refractory to conventional anticancer agents

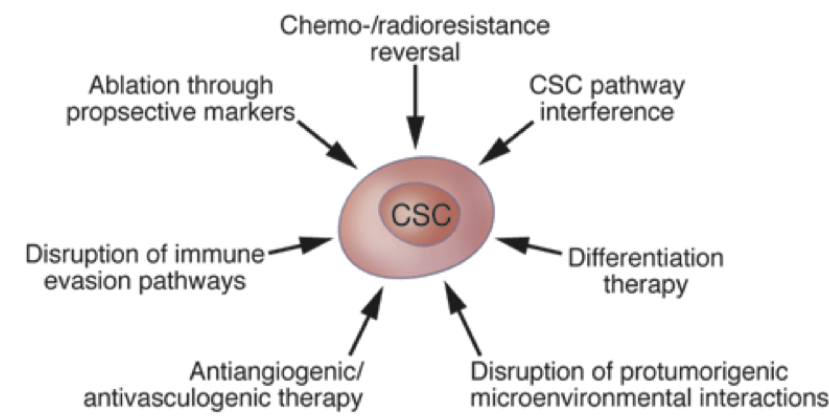

directed predominantly at the bulk tumor cell populations. (159)

Recent studies have revealed that cancer immunotherapy is a possible and promising candidate to target CSCs. Among the various immunological effector cells, cytotoxic T lymphocytes (CTL) are a good candidate for CSC-targeted immunotherapy as CTLs are antigenspecific effector cells.(176) In addition, identification of specific antigens or genetic alterations in CSCs may provide more specific targets for immunotherapy. ALDH, CD44, $\mathrm{CD} 133$, and $\mathrm{ErBb} 2$ have perfomed as markers to isolate CSCs from a number of tumor types in animal models and human tumors. They might serve as useful targets for CSC immunotherapy. In the end, since CSCs are regulated by interactions with CSC niche, these interactions may serve as additional targets for CSC immunotherapy. Targeting the tumor microenvironment, such as interrupting the immune cell, for example, myeloid-derived suppressor cells, and cytokines, for example, IL-6 and IL-8, as well as the immune checkpoint (programmed cell death 1 (PD1)/programmed death-ligand 1 (PDL1), etc.) may provide additional novel strategies to enhance the immunological targeting of CSCs. (176)

The growing number of reports regarding CSCs has significantly raised the complexity of our understanding of their basic and clinical biology. Some properties, such as drug resistance and migratory and invasive potential,

Figure 6. The therapeutic promise of CSC-directed targeting strategies.(159) (Adapted with permission from American Society for Clinical Investigation). 
are now attributed to CSCs in addition to their defining characteristics of tumorigenicity and self-renewal that suggests a major role in disease relapse and progression. Although these findings have served as a foundation to develop novel therapies, proof that CSCs are clinically relevant is still lacking. Improved overall survival resulting from the documented inhibition of CSCs will provide the most definitive evidence for their importance, but challenges exist in identifying the proper end-points to clinically assess therapies targeting these cells.(177)

\section{Conclusion}

The CSC hypothesis provides an attractive cellular mechanism to account for the therapeutic refractoriness and dormant behavior exhibited by many of these tumor. But recent observations have highlighted many complexities and challenges. The CSC phenotype can vary substantially between patients, tumors may harbor multiple phenotypically or genetically distinct CSCs, metastatic CSCs can evolve from primary CSCs, and tumor cells may undergo reversible phenotypic changes. The clinical relevance of CSCs remains a fundamental issue but preliminary findings show that specific targeting may be possible.

\section{References}

1. Merlo LM, Pepper JW, Reid BJ, Maley CC. Cancer as an evolutionary and ecological process. Nat Rev Cancer. 2006; 6: 924-35.

2. Greaves M, Maley CC. Clonal evolution in cancer. Nature. 2012; 481: 306-13.

3. Hanahan D, Weinberg RA. Hallmarks of cancer: the next generation. Cell. 2011; 144: 646-74.

4. Blanpain T. Tracing the cellular origin of cancer. Nat Cell Biol. 2013; 15: 126-34.

5. Badve S, Nakshatri H. Breast-cancer stem cells: beyond semantics. Lancet Oncol. 2012; 13: e43-8.

6. Qi Y, Li RM, Kong FM, Li H, Yu JP, Ren XB. How do tumor stem cells actively escape from host immunosurveillance? Biochem Biophys Res Commun. 2012; 420: 699-703.

7. Magee JA, Piskounova E, Morrison SJ. Cancer stem cells: impact, heterogeneity, and uncertainty. Cancer Cell. 2012; 21: 283-96.

8. Bonnet D, Dick JE. Human acute myeloid leukemia is organized as a hierarchy that originates from a primitive hematopoietic cell. Nat Med. 1997; 3: 730-7.

9. Al-Hajj M, Wicha MS, Benito-Hernandez A, Morrison SJ, Clarke MF. Prospective identification of tumorigenic breast cancer cells. Proc Natl Acad Sci USA. 2003; 100: 3983-8.

10. Gokmen-Polar Y, Badve SS. Cancer stem cells: nonbeliever's viewpoint. Clin Chem. 2013; 59: 208-10.

11. Jan M, Snyder TM, Corces-Zimmerman MR, Vyas P, Weissman IL, Quake SR, et al. Clonal evolution of preleukemic hematopoietic stem cells precedes human acute myeloid leukemia. Sci Transl Med. 2012; 4: 149ra18.

12. Azizi E, Wicha MS. Cancer stem cells: The evidence accumulates. Clin Chem. 2013; 59: 205-7.

13. Chen J, Li Y, Yu TS, McKay RM, Burns DK, Kernie SG, et al. A restricted cell population propagates glioblastoma growth after chemotherapy. Nature. 2012; 488: 522-6.

14. Driessens G, Beck B, Caauwe A, Simons BD, Blanpain C. Defining the mode of tumour growth by clonal analysis. Nature. 2012; 488: 527-30.

15. Schepers AG, Snippert HJ, Stange DE, van den Born M, van Es JH, van de Wetering $\mathrm{M}$, et al. Lineage tracing reveals Lgr5+ stem cell activity in mouse intestinal adenomas. Science. 2012; 337: 730-5.

16. Gilbertson RJ, Graham TA. Cancer: Resolving the stem-cell debate. Nature. 2012; 488: 462-3.

17. Clevers $\mathrm{H}$. The cancer stem cell: premises, promises and challenges. Nat Med. 2011; 17: 313-9.

18. Kreso A, Dick JE. Evolution of the cancer stem cell model. Cell Stem Cell. 2014; 14: 275-91.

19. Visvader JE, Lindeman GJ. Cancer stem cells: Current status and evolving complexities. Cell Stem Cell. 2012; 10: 717-28.

20. Matchett KB, Lappin TR. Concise reviews: cancer stem cells: from concept to cure. Stem Cells. 2014; 32: 2563-70.

21. Clarke MF, Dick JE, Dirks PB, Eaves CJ, Jamieson CH, Jones DL, et al. Cancer stem cells: perspectives on current status and future directions: AACR Workshop on cancer stem cells. Cancer Res. 2006; 66: 9339-44.

22. Nguyen LV, Vanner R, Dirks P, Eaves CJ. Cancer stem cells: an evolving concept. Nat Rev Cancer. 2012; 12: 133-43.

23. Sarry JE, Murphy K, Perry R, Sanchez PV, Secreto A, Keefer C, et al. Human acute myelogenous leukemia stem cells are rare and heterogeneous when assayed in NOD/SCID/IL2Rcc-deficient mice. J Clin Invest. 2011; 121: 384-95.

24. Li H, Tang DG. Prostate cancer stem cells and their potential roles in metastasis. J Surg Oncol. 2011; 103: 558-62.

25. Li C, Heidt DG, Dalerba P, Burant CF, Zhang L, Adsay V, et al. Identification of pancreatic cancer stem cells. Cancer Res. 2007; 67: 1030-7.

26. Ricci-Vitiani L, Lombardi DG, Pilozzi E, Biffoni M, Todaro M, Peschle $\mathrm{C}$, et al. Identification and expansion of human coloncancer-initiating cells. Nature. 2007; 445: 111-5.

27. Vermeulen L, Todaro M, de Sousa Mello F, Sprick MR, Kemper K, Perez Alea M, et al. Single-cell cloning of colon cancer stem cells reveals a multi-lineage differentiation capacity. Proc Natl Acad Sci USA. 2008; 105: 13427-32.

28. Liu S, Ginestier C, Ou SJ, Clouthier SG, Patel SH, Monville F, et al. Breast cancer stem cells are regulated by mesenchymal stem cells through cytokine networks. Cancer Res. 2011; 71: 614-24.

29. Charafe-Jauffret E, Ginestier C, Iovino F, Wicinski J, Cervera N, Finetti $\mathrm{P}$, et al. Breast cancer cell lines contain functional cancer stem cells with metastatic capacity and a distinct molecular signature. Cancer Res. 2009; 69: 1302-13.

30. Eramo A, Lotti F, Sette G, Pilozzi E, Biffoni M, Di Virgilio A, et al. Identification and expansion of the tumorigenic lung cancer stem cell population. Cell Death Differ. 2008; 15: 504-14

31. Wang J, Sakariassen PØ, Tsinkalovsky O, Immervoll H, Bøe SO, Svendsen A, et al. CD133 negative glioma cells form tumors in nude rats and give rise to CD133 positive cells. Int J Cancer. 2008; 122: 761-8

32. Pollard SM, Yoshikawa K, Clarke ID, Danovi D, Stricker S, Russell $\mathrm{R}$, et al. Glioma stem cell lines expanded in adherent culture have tumor-specific phenotypes and are suitable for chemical and genetic screens. Cell Stem Cell. 2009; 4: 568-80. 
33. Quintana E, Shackleton M, Foster HR, Fullen DR, Sabel MS, Johnson TM, et al. Phenotypic heterogeneity among tumorigenic melanoma cells from patients that is reversible and not hierarchically organized. Cancer Cell. 2010; 18: 510-23.

34. Girouard SD, Murphy GF. Melanoma stem cells: Not rare, but well done. Lab Invest. 2011; 91: 647-64.

35. Chaffer C, Brueckmann I, Scheel C, Kaestli AJ, Wiggins PA, Rodrigues LO, et al. Normal and neoplastic nonstem cells can spontaneously convert to a stem-like state. Proc Natl Acad Sci USA. 2011; 108: 7950-5.

36. Iliopoulos D, Hirsch H, Wang G, Struhl K. Inducible formation of breast cancer stem cells and their dynamic equilibrium with nonstem cancer cells via IL6 secretion. Proc Natl Acad Sci USA. 2011; 108: 1397-402.

37. Lander AD. The 'stem cell' concept: Is it holding us back? J Biol. 2009; 8: 70.

38. Vermeulen L, Sprick MR, Kemper K, Stassi G, Medema JP. Cancer stem cells: old concepts, new insights. Cell Death Differ. 2008; 15: 947-58.

39. Vermeulen L, de Sousa e Melo F, Richel DJ, Medema JP. The developing cancer stem-cell model: clinical challenges and opportunities. Lancet Oncol. 2012; 13: e83-9.

40. Medema JP. Cancer stem cells: the challenges ahead. Nat Cell Biol. 2013; 15: 338-44.

41. Mani SA, Guo W, Liao MJ, Eaton EN, Ayyanan A, Zhou AY, et al. The epithelial-mesenchymal transition generates cells with properties of stem cells. Cell. 2008; 133: 704-15.

42. Morel AP, Lièvre M, Thomas C, Hinkal G, Ansieau S, Puisieux A. Generation of breast cancer stem cells through epithelialmesenchymal transition. PLoS ONE. 2008; 3: e2888.

43. Scheel C, Eaton EN, Li SH, Chaffer CL, Reinhardt F, Kah KJ, et al. Paracrine and autocrine signals induce and maintain mesenchymal and stem cell states in the breast. Cell. 2011; 145: 926-40.

44. Brabletz T, Jung A, Spaderna S, Hlubek F, Kirchner T. Opinion: migrating cancer stem cells: an integrated concept of malignant tumour progression. Nat Rev Cancer. 2005; 5: 744-9.

45. Yang J, Weinberg RA. Epithelial-mesenchymal transition: at the crossroads of development and tumor metastasis. Dev Cell. 2008; 14: 818-29.

46. Fuchs E. The tortoise and the hair: slow-cycling cells in the stem cell race. Cell. 2009; 137: 811-9.

47. Essers MA, Trumpp A. Targeting leukemic stem cells by breaking their dormancy. Mol Oncol. 2010; 4: 443-50.

48. Zhou BB, Zhang H, Damelin M, Geles KG, Grindley JC, Dirks PB. Tumour-initiating cells: challenges and opportunities for anticancer drug discovery. Nat Rev Drug Discov. 2009; 8: 806-23.

49. Bao S, Wu Q, McLendon RE, Hao Y, Shi Q, Hjelmeland AB, et al. Glioma stem cells promote radioresistance by preferential activation of the DNA damage response. Nature. 2006; 444: 75660 .

50. Li X, Lewis MT, Huang J, Gutierrez C, Osborne CK, Wu MF, et al. Intrinsic resistance of tumorigenic breast cancer cells to chemotherapy. J Natl Cancer Inst. 2008; 100: 672-9.

51. Diehn M, Cho RW, Lobo NA, Kalisky T, Dorie MJ, Kulp AN, et al. Association of reactive oxygen species levels and radioresistance in cancer stem cells. Nature. 2009; 458: 780-3.

52. O'Hare T, Corbin AS, Druker BJ. Targeted CML therapy: controlling drug resistance, seeking cure. Curr Opin Genet Dev. 2006; 16: 929.

53. Oravecz-Wilson KI, Philips ST, Yilmaz OH, Ames HM, Li L, Crawford BD, et al. Persistence of leukemia-initiating cells in a conditional knockin model of an imatinib-responsive myeloproliferative disorder. Cancer Cell. 2009; 16: 137-48.

54. Masters JR, Koberle B. Curing metastatic cancer: lessons from testicular germ-cell tumours. Nat Rev Cancer. 2003; 3: 517-25.

55. Sikic BI. Natural and acquired resistance to cancer therapies. In: Mendelsohn J, Howley PM, Israel MA, Gray JW, Thompson CB, editors. The Molecular Basis of Cancer. 3rd ed. Philadelphia: Saunders/Elsevier; 2008. p.583-92.

56. Read TA, Fogarty MP, Markant SL, McLendon RE, Wei Z, Ellison DW, et al. Identification of CD15 as a marker for tumor-propagating cells in a mouse model of medulloblastoma. Cancer Cell. 2009; 15: 135-47.

57. Son MJ, Woolard K, Nam DH, Lee J, Fine HA. SSEA-1 is an enrichment marker for tumor-initiating cells in human glioblastoma. Cell Stem Cell. 2009; 4: 440-52.

58. Ward RJ, Lee L, Graham K, Satkunendran T, Yoshikawa K, Ling E, et al. Multipotent CD15+ cancer stem cells in patched-1-deficient mouse medulloblastoma. Cancer Res. 2009; 69: 4682-90.

59. Lathia JD, Gallagher J, Heddleston JM, Wang J, Eyler CE, Macswords $\mathrm{J}$, et al. Integrin alpha 6 regulates glioblastoma stem cells. Cell Stem Cell. 2010; 6: 421-32.

60. Curtis SJ, Sinkevicius KW, Li D, Lau AN, Roach RR, Zamponi $\mathrm{R}$, et al. Primary tumor genotype is an important determinant in identification of lung cancer propagating cells. Cell Stem Cell. 2010; 7: 127-33.

61. Meyer MJ, Fleming JM, Lin AF, Hussnain SA, Ginsburg E, Vonderhaar BK. CD44posCD49fhiCD133/2hi defines xenograftinitiating cells in estrogen receptor-negative breast cancer. Cancer Res. 2010; 70: 4624-33.

62. Ginestier C, Hur MH, Charafe-Jauffret E, Monville F, Dutcher J, Brown $\mathrm{M}$, et al. ALDH1 is a marker of normal and malignant human mammary stem cells and a predictor of poor clinical outcome. Cell Stem Cell. 2007; 1: 555-67.

63. Dalerba P, Dylla SJ, Park IK, Liu R, Wang X, Cho RW, et al Phenotypic characterization of human colorectal cancer stem cells. Proc Natl Acad Sci USA. 2007; 104: 10158-63.

64. Hermann PC, Huber SL, Herrler T, Aicher A, Ellwart JW, Guba M, et al. Distinct populations of cancer stem cells determine tumor growth and metastatic activity in human pancreatic cancer. Cell Stem Cell. 2007; 1: 313-23.

65. Curley MD, Therrien VA, Cummings CL, Sergent PA, Koulouris CR, Friel AM, et al. CD133 expression defines a tumor initiating cell population in primary human ovarian cancer. Stem Cells. 2009; 27: 2875-83.

66. Stewart JM, Shaw PA, Gedye C, Bernardini MQ, Neel BG, Ailles LE. Phenotypic heterogeneity and instability of human ovarian tumorinitiating cells. Proc Natl Acad Sci USA. 2011; 108: 6468-73.

67. Zhang WC, Shyh-Chang N, Yang H, Rai A, Umashankar S, Ma S, et al. Glycine decarboxylase activity drives non-small cell lung cancer tumor-initiating cells and tumorigenesis. Cell. 2012; 148: 259-72.

68. Burk U, Schubert J, Wellner U, Schmalhofer O, Vincan E, Spaderna $\mathrm{S}$, et al. A reciprocal repression between ZEB1 and members of the miR-200 family promotes EMT and invasion in cancer cells. EMBO Rep. 2008; 9: 582-9.

69. Brabletz T. To differentiate or not: routes towards metastasis. Nat Rev Cancer. 2012; 12: 425-36.

70. Park SM, Gaur AB, Lengyel E, Peter ME. The miR-200 family determines the epithelial phenotype of cancer cells by targeting the E-cadherin repressors ZEB1 and ZEB2. Genes Dev. 2008; 22: 894907.

71. Todaro M, Francipane MG, Medema JP, Stassi G. Colon cancer stem cells: promise of targeted therapy. Gastroenterology. 2010; 138: 2151-62. 
72. Xie X, Teknos TN, Pan Q. Are all cancer stem cells created equal? Stem Cell Transl Med. 2014; 3: 1111-5.

73. Schwitalla S, Fingerle AA, Cammareri P, Nebelsiek T, Göktuna SI, Ziegler PK, et al. Intestinal tumorigenesis initiated by dedifferentiation and acquisition of stem-cell-like properties. Cell. 2013; 152: 25-38.

74. Ischenko I, Zhi J, Moll UM, Nemajerova A, Petrenko O. Direct reprogramming by oncogenic Ras and Myc. Proc Natl Acad Sci USA. 2013 ; 110: 3937-42.

75. Niwa T, Tsukamoto T, Toyoda T, Mori A, Tanaka H, Maekita T, et al. Inflammatory processes triggered by Helicobacter pylori infection cause aberrant DNA methylation in gastric epithelial cells. Cancer Res. 2010; 70: 1430-40.

76. Lawrence MS, Stojanov P, Mermel CH, Robinson JT, Garraway LA, Golub TR, et al. Discovery and saturation analysis of cancer genes across 21 tumour types. Nature. 2014; 505: 495-501.

77. Yamada Y, Haga H, Yamada Y. Concise review: dedifferentiation meets cancer development: proof of concept for epigenetic cancer. Stem Cells Transl Med. 2014; 3: 1182-7.

78. Ben-Porath I, Thomson MW, Carey VJ, Ge R, Bell GW, Regev A, et al. An embryonic stem cell-like gene expression signature in poorly differentiated aggressive human tumors. Nat Genet. 2008; 40: 499507.

79. Folmes CD, Nelson TJ, Martinez-Fernandez A, Arrell DK, Lindor JZ, Dzeja PP, et al. Somatic oxidative bioenergetics transitions into pluripotency-dependent glycolysis to facilitate nuclear reprogramming. Cell Metab. 2011; 14: 264-71.

80. Hong H, Takahashi K, Ichisaka T, Aoi T, Kanagawa O, Nakagawa M, et al. Suppression of induced pluripotent stem cell generation by the p53-p21 pathway. Nature. 2009; 460: 1132-5.

81. Hochedlinger K, Yamada Y, Beard C, Jaenisch R. Ectopic expression of Oct-4 blocks progenitor-cell differentiation and causes dysplasia in epithelial tissues. Cell. 2005; 121: 465-77.

82. Ohnisi K, Semi K, Yamamoto T, Shimizu M, Tanaka A, Mitsunaga $\mathrm{K}$, et al. Premature termination of reprogramming in vivo leads to cancer development through altered epigenetic regulation. Cell. 2014; 156: 663-77.

83. Friedmann-Morvinsky D, Verma IM. Dedifferentiation and reprogramming: origins of cancer stem cells. EMBO Rep. 2014; 25: 244-53.

84. Riggi N, Suva ML, De Vito C, Provero P, Stehle JC, Baumer K, et al. EWS-FLI-1 modulates miRNA145 and SOX2 expression to initiate mesenchymal stem cell reprogramming toward Ewing sarcoma cancer stem cells. Genes Dev. 2010; 24: 916-32.

85. Sarkar A, Hochedlinger K. The sox family of transcription factors: versatile regulators of stem and progenitor cell fate. Cell Stem Cell. 2013; 12: 15-30.

86. Yamanaka S. Induced pluripotent stem cells: past, present, and future. Cell Stem Cell. 2012; 10: 678-84.

87. Dang CV. MYC on the path to cancer. Cell. 2012; 149: 22-35.

88. Morris SA, Daley GQ. A blueprint for engineering cell fate: current technologies to reprogram cell identity. Cell Res. 2013; 23: 33-48.

89. Daley GQ. Common themes of dedifferentiation in somatic cell reprogramming and cancer. Cold Spring Harb Symp Quant Biol. 2008; 73: 171-4.

90. Thiery JP, Sleeman JP. Complex networks orchestrate epithelialmesenchymal transitions. Nature Rev Mol Cell Biol. 2006; 7: 13142.

91. Thiery JP, Acloque H, Huang RY, Nieto MA. Epithelial-mesenchymal transitions in development and disease. Cell. 2009; 139: 871-90.

92. Kalluri R, Weinberg RA. The basics of epithelial-mesenchymal transition. J Clin Invest. 2009; 119: 1420-8.
93. Chapman HA. Epithelial-mesenchymal interactions in pulmonary fibrosis. Annu Rev Physiol. 2011; 73: 413-35.

94. Lamouille S, Xu J, Derynck R. Molecular mechanism of epithelialmesenchymal transition. Nat Rev Mol Cell Biol. 2014; 15: 178-96.

95. Wanami LS, Chen HY, Peiro S, Garcia de Herreros A, Bachelder RE. Vascular endothelial growth factor-A stimulates Snail expression in breast tumor cells: implications for tumor progression. Exp Cell Res. 2008; 314: 2448-53.

96. Yang AD, Camp ER, Fan F, Shen L, Gray MJ, Liu W, et al. Vascular endothelial growth factor receptor-1 activation mediates epithelial to mesenchymal transition in human pancreatic carcinoma cells. Cancer Res. 2006; 66: 46-51.

97. Peinado H, Marin F, Cubillo E, Stark HJ, Fusenig N, Nieto MA, et al. Snail and E47 repressors of E-cadherin induce distinct invasive and angiogenic properties in vivo. J Cell Sci. 2004; 117: 2827-39.

98. Zhang J, Oh KH, Xu H, Margetts PJ. Vascular endothelial growth factor expression in peritoneal mesothelial cells undergoing transdifferentiation. Perit Dial Int. 2008; 28: 497-504.

99. Knutson KL, Lu H, Stone B, Reiman JM, Behrens MD, Prosperi CM, et al. Immunoediting of cancers may lead to epithelial mesenchymal transition. J Immunol. 2006; 177: 1526-33.

100. Moody SE, Sarkisian CJ, Hahn KT, Gunther EJ, Pickup S, Dugan KD, et al. Conditional activation of Neu in the mammary epithelium of transgenic mice results in reversible pulmonary metastasis. Cancer Cell. 2002; 2: 451-61.

101. Yang AD, Fan F, Camp ER, van Buren G, Liu W, Somcio R, et al. Chronic oxaliplatin resistance induces epithelial-to-mesenchymal transition in colorectal cancer cell lines. Clin Cancer Res. 2006; 12: 4147-53.

102. Kajiyama H, Shibata K, Terauchi M, Yamashita M, Ino K, Nawa A, et al. Chemoresistance to paclitaxel induces epithelial-mesenchymal transition and enhances metastatic potential for epithelial ovarian carcinoma cells. Int J Oncol. 2007; 31: 277-83.

103. Cheng GZ, Chan J, Wang Q, Zhang W, Sun CD, Wang LH. Twist transcriptionally up-regulates AKT2 in breast cancer cells leading to increased migration, invasion, and resistance to paclitaxel. Cancer Res. 2007; 67: 1979-87.

104. Li QQ, Xu JD, Wang WJ, Cao XX, Chen Q, Tang F, et al. Twist1mediated adriamycin-induced epithelial-mesenchymal transition relates to multidrug resistance and invasive potential in breast cancer cells. Clin Cancer Res. 2009; 15: 2657-65.

105. Scheel C, Weinberg RA. Cancer stem cells and epithelialmesenchymal transition: concepts and molecular links. Semin Cancer Biol. 2012; 22: 396-403.

106. Shipitsin M, Campbell LL, Argani P, Weremowicz S, BloushtainQimron N, Yao J, et al. Molecular definition of breast tumor heterogeneity. Cancer Cell. 2007; 11: 259-73.

107. Vermeulen L, De Sousa E Melo F, van der Heijden M, Cameron K, de Jong JH, Borovski T, et al. Wnt activity defines colon cancer stem cells and is regulated by the microenvironment. Nat Cell Biol. 2010; 12: 468-76.

108. Brabletz T, Jung A, Hermann K, Günther K, Hohenberger W, Kirchner $\mathrm{T}$, et al. Nuclear overexpression of the oncoprotein $\beta$-catenin in colorectal cancer is localized predominantly at the invasion front. Pathol Res Pract. 1998; 194: 701-4.

109. Espinoza I, Pochampally R, Xing F, Watabe K, Miele L. Notch signaling: targeting cancer stem cells and epithelial-to-mesenchymal transition. Onco Targets Ther. 2013; 6: 1249-59.

110. Ma J, Xia J, Miele L, Sarkar FH, Wang Z. Notch signaling pathway in pancreatic cancer progression. Pancreat Disord Ther. 2013; 3: pii: 1000114.

111. Palagani V, El Khatib M, Kossatz U, Bozko P, Müller MR, Manns 
MP, et al. Epithelial mesenchymal transition and pancreatic tumor initiating CD44+/EpCAM+ cells are inhibited by $\gamma$-secretase inhibitor IX. PLoS ONE. 2012; 7: e46514.

112. Chua KN, Ma J, Thiery JP. Targeted therapies in control of EMT in carcinoma and fibrosis. Drug Discov Today. 2008; 4: 261-7.

113. Frederick BA, Helfrich BA, Coldren CD, Zheng D, Chan D, Bunn PA Jr, et al. Epithelial to mesenchymal transition predicts gefitinib resistance in cell lines of head and neck squamous cell carcinoma and non-small cell lung carcinoma. Mol Cancer Ther. 2007; 6: 1683-91.

114. Thomson S, Buck E, Petti F, Griffin G, Brown E, Ramnarine N, et al. Epithelial to mesenchymal transition is a determinant of sensitivity of non-small-cell lung carcinoma cell lines and xenografts to epidermal growth factor receptor inhibition. Cancer Res. 2005; 65: 9455-62.

115. Yauch RL, Januario T, Eberhard DA, Cavet G, Zhu W, Fu L, et al. Epithelial versus mesenchymal phenotype determines in vitro sensitivity and predicts clinical activity of erlotinib in lung cancer patients. Clin Cancer Res. 2005; 11: 8686-98.

116. Gupta PB, Onder TT, Jiang G, Tao K, Kuperwasser C, Weinberg RA, et al. Identification of selective inhibitors of cancer stem cells by high-throughput screening. Cell. 2009; 138: 645-59.

117. Kreso A, O’Brien CA, van Galen P, Gan OI, Notta F, Brown AM, et al. Variable clonal repopulation dynamics influence chemotherapy response in colorectal cancer. Science. 2013; 339: 543-8.

118. Voog J, Jones DL. Stem cells and the niche: a dynamic duo. Cell Stem Cell. 2010; 6: 103-15.

119. Korkaya H, Liu S, Wicha MS. Breast cancer stem cells, cytokine networks, and the tumor microenvironment. J Clin Invest. 2011; 121: 3804-9.

120. Hanahan D, Coussens LM. Accessories to the crime: functions of cells recruited to the tumor microenvironment. Cancer Cell. 2012; 21: 309-22.

121. Fessler E, Dijkgraaf FE, De Sousa E Melo F, Medema JP. Cancer stem cell dynamics in tumor progression and metastasis: is the microenvironment to blame? Cancer Lett. 2013; 341, 97-104.

122. Plaks V, Kong N, Werb Z. The cancer stem cell niche: How essential is the niche in regulating stemness of tumor cells? Cell Stem Cell. 2015; 16: 225-38.

123. Oskarsson T, Batlle E, Massague J. Metastatic stem cells: sources, niches, and vital pathways. Cell Stem Cell. 2014; 14: 306-21.

124. Chambers AF, Groom AC, MacDonald IC. Dissemination and growth of cancer cells in metastatic sites. Nat Rev Cancer. 2002; 2: 563-72.

125. Hüsemann Y, Geigl JB, Schubert F, Musiani P, Meyer M, Burghart E, et al. Systemic spread is an early step in breast cancer. Cancer Cell . 2008; 13: 58-68.

126. Kouros-Mehr H, Bechis SK, Slorach EM, Littlepage LE, Egeblad M, Ewald AJ, et al. GATA-3 links tumor differentiation and dissemination in a luminal breast cancer model. Cancer Cell. 2008; 13: 141-52.

127. Nguyen DX, Bos PD, Massague J. Metastasis: from dissemination to organ- specific colonization. Nature Rev Cancer. 2009; 9: 274-84.

128. Hess KR, Varadhachary GR, Taylor SH, Wei W, Raber MN, Lenzi $\mathrm{R}$, et al. Metastatic patterns in adenocarcinoma. Cancer. 2006; 106: 1624-33.

129. Malanchi I, Santamaria-Martinez A, Susanto E, Peng H, Lehr HP, Delaloye JF, et al. Interactions between cancer stem cells and their niche govern metastatic colonization. Nature. 2011; 481: 85-9.

130. Cunha GR. Mesenchymal-epithelial interactions: past, present, and future. Differentiation. 2008; 76: 578-86.

131. Puri S, Hebrok M. Cellular plasticity within the pancreas: lessons learned from development. Dev Cell. 2010; 18: 342-56.
132. Wiseman BS, Werb Z. Stromal effects on mammary gland development and breast cancer. Science. 2002; 296: 1046-9.

133. Egeblad M, Ewald AJ, Askautrud HA, Truitt ML, Welm BE, Bainbridge E, et al. Visualizing stromal cell dynamics in different tumor microenvironments by spinning disk confocal microscopy. Dis Model Mech. 2008; 1: 155-67.

134. Lin EY, Jones JG, Li P, Zhu L, Whitney KD, Muller WJ, et al. Progression to malignancy in the polyoma middle $\mathrm{T}$ oncoprotein mouse breast cancer model provides a reliable model for human diseases. Am J Pathol. 2003; 163: 2113-26.

135. Levental KR, Yu H, Kass L, Lakins JN, Egeblad M, Erler JT, et al. Matrix crosslinking forces tumor progression by enhancing integrin signaling. Cell. 2009; 139: 891-906.

136. Lin EY, Li JF, Gnatovskiy L, Deng Y, Zhu L, Grzesik DA, et al. Macrophages regulate the angiogenic switch in a mouse model of breast cancer. Cancer Res. 2006; 66: 11238-46.

137. Provenzano PP, Eliceiri KW, Campbell JM, Inman D, White JG, Keely PJ. Collagen reorganization at the tumor-stromal interface facilitates local invasion. BMC Med. 2006; 4: 38

138. Egeblad M, Nakasone ES, Werb Z. Tumors as organs: compplex tissue that interface with the entire organism. Dev Cell. 2010; 18 884-901.

139. Lee CYF, Diehn M. Mechanism of radioresistance in cancer stem cells. In: L Allan AL, editor. Cancer Stem Cells in Solif Tumors, Stem Cell Biology and Regenerative Medicine. New York: Humana Press; 2011. p.345-60.

140. Bertolini G, Roz L, Perego P, Tortoreto M, Fontanella E, Gatti L, et al. Highly tumorigenic lung cancer $\mathrm{CD} 133+$ cells display stem-like features and are spared by cisplatin treatment. Proc Natl Acad Sci USA. 2009; 106: 16281-6.

141. Cao L, Bombard J, Cintron K, Sheedy J, Weetall ML, Davis TW. BMI1 as a novel target for drug discovery in cancer. J Cell Biochem. 2011; 112: 2729-41.

142. Crea F, Serrat MAD, Hurt EM, Thomas SB, Danesi R, Farrar WL. BMI1 silencing enhances docetaxel activity and impairs antioxidant response in prostate cancer. Int J Cancer. 2011; 128: 1946-54.

143. Lapidot T, Sirard C, Vormoor J, Murdoch B, Hoang T, Caceres-Cortes $\mathrm{J}$, et al. A cell initiating human acute myeloid leukaemia after transplantation into SCID mice. Nature. 1994; 367: 645-8.

144. Huber GF, Albinger-Hegyi A, Soltermann A, Roessle M, Graf N, Haerle SK, et al. Expression patterns of BMI1 and p16 significantly correlate with overall, disease-specific, and recurrence-free survival in oropharyngeal squamous cell carcinoma. Cancer. 2011; 117: 4659-70.

145. Yin T, Wei H, Gou S, Shi P, Yang Z, Zhao G, et al. Cancer stem-like cells enriched in Panc-1 spheres possess increased migration ability and resistance to gemcitabine. Int J Mol Sci. 2011; 12: 1595-604.

146. Raaphorst FM. Deregulated expression of Polycomb-group oncogenes in human malignant lymphomas and epithelial tumors. Hum Mol Genet. 2005; 14: R93-100.

147. Park IK, Morrison SJ, Clarke MF. Bmi1, stem cells, and senescence regulation. J Clin Invest. 2004; 113: 175-9.

148. Cui H, Hu B, Li T, Ma J, Alam G, Gunning WT, et al. Bmi-1 is essential for the tumorigenicity of neuroblastoma cells. Am J Pathol. 2007; 170: 1370-8.

149. Mihic-Probst D, Kuster A, Kilgus S, Bode-Lesniewska B, IngoldHeppner B, Leung C, et al. Consistent expression of the stem cell renewal factor BMI1 in primary and metastatic melanoma. Int $\mathrm{J}$ Cancer. 2007; 121: 1764-70.

150. Jacobs JJ, Scheijen B, Voncken JW, Kieboom K, Berns A, van Lohuizen M. BMI1 collaborates with c-Myc in tumorigenesis by inhibiting c-Myc-induced apoptosis via INK4a/ARF. Genes Dev. 
1999; 13: 2678-90.

151. Zhang S, Balch C, Chan MW, Lai HC, Matei D, Schilder JM, et al. Identification and characterization of ovarian cancer-initiating cells from primary human tumors. Cancer Res. 2008; 68: 4311-20.

152. Wang E, Bhattacharyya S, Szabolcs A, Rodriguez-Aguayo C, Jennings NB, Lopez-Berestein G, et al. Enhancing chemotherapy response with BMI1 silencing in ovarian cancer. PLoS One. 2011; 6: e17918.

153. Friedman GK, Gillespie GY. Cancer stem cells and pediatric solid tumors. Cancers. 2011; 3: 298-318.

154. Lessard J, Sauvageau G. Bmi-1 determines the proliferative capacity of normal and leukaemic stem cells. Nature. 2003; 423: 255-60.

155. Crea F, Danesi R, Farrar WL. Cancer stem cell epigenetic and chemoresistance. Epigenome. 2009; 1: 63-79.

156. Siddique HR, Saleem M. Role of BMI1, a stem cell factor, in cancer recurrence and chemoresistance: Preclinical and clinical evidences. Stem Cells. 2012; 30: 372-8.

157. Gilbert CA, Ross AH. Cancer stem cells: Cell culture, markers, and targets for new therapies. J Cell Biochem. 2009; 108: 1031-8.

158. Yuan S, Wang F, Chen G, Zhang H, Feng L, Wang L, et al. Effective elimination of cancer stem cells by a novel drug combination strategy. Stem Cells. 2013; 31: 23-34.

159. Frank NY, Schatton T, Frank MH. The therapeutic promise of the cancer stem cell concept. J Clin Invest. 2010; 120: 41-50.

160. Gottesman MM, Fojo T, Bates SE. Multidrug resistance in cancer: role of ATP-dependent transporters. Nat Rev Cancer. 2002; 2: 4858.

161. Dean M, Fojo T, Bates S. Tumour stem cells and drug resistance. Nat Rev Cancer. 2005; 5: 275-84.

162. Ishikawa F, Yoshida S, Saito Y, Hijikata A, Kitamura H, Tanaka S, et al. Chemotherapy-resistant human AML stem cells home to and engraft within the bone-marrow endosteal region. Nat Biotechnol. 2007; 25: 1315-21.

163. Costello RT, Mallet F, Gaugler B, Sainty D, Arnoulet C, Gastaut JA, et al. Human acute myeloid leukemia CD34+/CD38- progenitor cells have decreased sensitivity to chemotherapy and Fas-induced apoptosis, reduced immunogenicity, and impaired dendritic cell transformation capacities. Cancer Res. 2000; 60: 4403-11.

164. de Grouw EP, Raaijmakers MH, Boezeman JB, van der Reijden BA, van de Locht LT, de Witte TJ, et al. Preferential expression of a high number of ATP binding cassette transporters in both normal and leukemic CD34+CD38- cells. Leukemia. 2006; 20: 750-4.

165. Ito K, Bernardi R, Morotti A, Matsuoka S, Saglio G, Ikeda Y, et al. PML targeting eradicates quiescent leukaemia-initiating cells. Nature. 2008; 453: 1072-8.

166. Michor F, Hughes TP, Iwasa Y, Branford S, Shah NP, Sawyers CL, et al. Dynamics of chronic myeloid leukaemia. Nature. 2005; 435: 1267-70.

167. Viale A, De Franco F, Orleth A, Cambiaghi V, Giuliani V, Bossi D, et al. Cell-cycle restriction limits DNA damage and maintains selfrenewal of leukaemia stem cells. Nature. 2009; 457: 51-6.

168. Wulf GG, Wang RY, Kuehnle I, Weidner D, Marini F, Brenner MK, et al. A leukemic stem cell with intrinsic drug efflux capacity in acute myeloid leukemia. Blood. 2001; 98: 1166-73.

169. Schatton T, Murphy GF, Frank NY, Yamaura K, Waaga-Gasser AM, Gasser M, et al. Identification of cells initiating human melanomas. Nature. 2008; 451: 345-9.

170. Frank NY, Margaryan A, Huang Y, Schatton T, Waaga-Gasser AM, Gasser $\mathrm{M}$, et al. ABCB5-mediated doxorubicin transport and chemoresistance in human malignant melanoma. Cancer Res. 2005; 65: 4320-33.

171. Eramo A, Ricci-Vitiani L, Zeuner A, Pallini R, Lotti F, Sette G, et al. Chemotherapy resistance of glioblastoma stem cells. Cell Death Differ. 2006; 13: 1238-41.

172. Yu F, Yao H, Zhu P, Zhang X, Pan Q, Gong C, et al. let-7 regulates self renewal and tumorigenicity of breast cancer cells. Cell. 2007; 131: 1109-23.

173. Dylla SJ, Beviglia L, Park IK, Chartier C, Raval J, Ngan L, et al. Colorectal cancer stem cells are enriched in xenogeneic tumors following chemotherapy. PLoS One. 2008; 3: e2428.

174. Phillips TM, McBride WH, Pajonk F. The response of CD24(-/low)/ CD44+ breast cancer-initiating cells to radiation. J Natl Cancer Inst. 2006; 98: 1777-85.

175. Saijo H, Hirohashi Y, Torigoe T, Kochin V, Takahashi H, Sato N. Cytotoxic T lymphocytes: the future of cancer stem cell eradication? Immunotherapy. 2013; 5: 549-51.

176. Pan Q, Li Q, Liu S, Ning N, Zhang X, Xu Y, et al. Concise review: Targeting cancer stem cells using immunologic approaches. Stem Cells. 2015; 33: 2085-92.

177. Rasheed ZA, Kowalski J, Smith BD, Matsui W. Concise review: Emerging concepts in clinical targeting of cancer stem cells. Stem Cells. 2011; 29: 883-7. 